\title{
Monitoring odpadové obslužnosti pro tříděné složky komunálního odpadu na území Hlavního města Prahy
}

\section{DAGMAR VOLOŠINOVÁ, ROBERT KOŘÍNEK, MARCELA MAKOVCOVÁ}

Klíčová slova: odpad - odpadová obslužnost - třídění - komunální odpad - monitoring

\section{SOUHRN}

\begin{abstract}
Management každé obce, kraje, potažmo státu potřebuje ke svému rozhodování a plánování základní vstupní data, která dokladují aktuální skutečnost. Nejjednodušší způsob, kterým Ize získat data o produkci odpadu a nakládání s ním, je monitoring $v$ predem nastavených pravidelných intervalech. $V$ tomto článku je popsán průběh a částečné výsledky monitoringu odpadové obslužnosti Hlavního města Prahy, který probíhá v rámci řešení projektu „Odpady a předcházení jejich vzniku - praktické postupy a činnosti při realizaci závazků krajského Plánu odpadového hospodářství hlavního města Prahy".
\end{abstract}

\section{ÚVOD}

Cílem předloženého príspěvku je prezentovat dosud získané výsledky monitoringu odpadové obslužnosti tříděných složek komunálního odpadu (KO) ve vybraných lokalitách na území Hlavního města Prahy (HMP). Jedná se o nejucelenější rozbor odpadové obslužnosti, který byl na území hlavního města doposud proveden. Ve spolupráci s Pražskými službami, a. s., a oddělením odpadů Magistrátu hlavního města Prahy (MHMP) jsou získávány informace z šesti oblastí, které představují zástupce tři typů zástaveb, které se nacházejí na území HMP. Cílem projektu je přesné vyhodnocení stávajícího stavu produkce komunálních odpadů v kraji HMP a identifikaci inovativních způsobů nakládání se tříděnými složkami a zbytkovým směsným komunálním odpadem s cílem plnění závazků krajského Plánu odpadového hospodářství hlavního města Prahy (KPOH HMP) [1]. Nedílnou součástí projektu je také problematika správného nastavení opatření pro predcházení vzniku odpadů. Znalost výchozího stavu je dưležitým předpokladem k nastavení reálně dosažitelných cílů a indikátorů jejich plnění v oblasti nakládání s komunálními (a jim podobnými) odpady.

\section{METODIKA}

Pro metodiku hodnocení odpadové obslužnosti byl zvolen měsíčně se opakující monitoring čistoty tříděných složek $\mathrm{KO}$, čistoty okolí kontejnerových hnízd (KH) a monitorovaných oblastí. Součástí hodnocení je i rozbor směsného komunálního odpadu (SKO) sváženého ze tří monitorovaných lokalit, tj. zástupců tří typů zástaveb (sídlištní, vilová a smíšená - resp. centra města). Na počátku byly ve spolupráci s oddělením odpadů MHMP a zástupci Pražských služeb, a. s., vybrány dvě lokality pro každý typ zástavby. Pro vilovou zástavbu je to stará část Modřan a Újezdu nad Lesy, sídlištní zástavbu představuje sídliště Modřany, Petrovice a Horní Měcholupy, smíšenou či centrální zástavbu část Prahy 1 a Prahy 6. Pro každý typ zástavby jsou rozlohy sledovaných lokalit obdobně velké s podobnou hustotou osídlení [2]. Největší oblastí je centrum Prahy 1, a to z důvodu trasy svozu směsného komunálního odpadu. Od Pražských služeb, a. s., byly obdrženy konkrétní adresy kontejnerových hnízd a časový rozpis svozů, podle kterých jsou daná místa obcházena v co nejbližší době před plánovaným svozem nejčastěji vyvážených komodit, tj. plastu a papíru. Při každé obchůzce je místo nafoceno, do tabulek zaznamenána využitelnost kapacity kontejneru, čistota separované složky a okolí jak kontejnerů, tak celé sledované oblasti. Je sledován „littering" (pro potřeby monitoringu se zaměřujeme na volně pohozený odpad v místech KH), vizuální kontrola skladby obsahu pouličních odpadkových košů i náhodné chování obyvatel príi separaci odpadu. Získaná data jsou průběžně zpracovávána a vyhodnocována se snahou zjistit, které faktory a jak ovlivňují sledované ukazatele. Pro toto hodnocení se zatím jako nezbytná jeví demografická vizualizace daných míst, díky které lze názorněji zachytit vlivy jak uvnitř (např. pěší trasy na MHD, ke školám či obchodním a zdravotním centrům, blízkost restaurací či zábavných podniků), tak i vně (např. blízkost hlavních príjezdových tras z okrajových oblastí nebo spádových obcí, parkoviště $P+R$ apod.) monitorované oblasti.

Z dodaného souboru, který obsahoval prostorové informace o jednotlivých lokalitách pro odkládání tříděného odpadu, byla vytvořena $v$ prostředí ArcGIS geoprostorová bodová vrstva (shapefile) v souřadném systému JTSK. Tato bodová vrstva obsahuje atributy s informací o souřadnicích jednotlivých kontejnerových hnízd a jejich adresou. Podle zadaných parametrů byl vytvořen kolem jednotlivých kontejnerových hnízd buffer (obálka) o velikosti donáškové vzdálenosti 100 metrů. Následně byla provedena v prostředí ArcGIS prostorová analýza, která vycházela z bodové vrstvy a vytvořeného bufferu donáškové vzdálenosti.

Výsledkem celého procesu je nová geoprostorová vrstva překrytí jednotlivých donáškových vzdáleností (obr. 1).

Všechny sledované oblasti včetně map a fotodokumentací jednotlivých kontejnerových hnízd jsou uvedeny na internetových stránkách projektu [3].

\section{VÝSLEDKY}

Počty sledovaných KH včetně jejich kapacit jsou uvedeny v tabulce 1. Z dosud získaných dat, jejichž sběr bude ukončen v první polovině roku 2020, Ize uvést následující: 

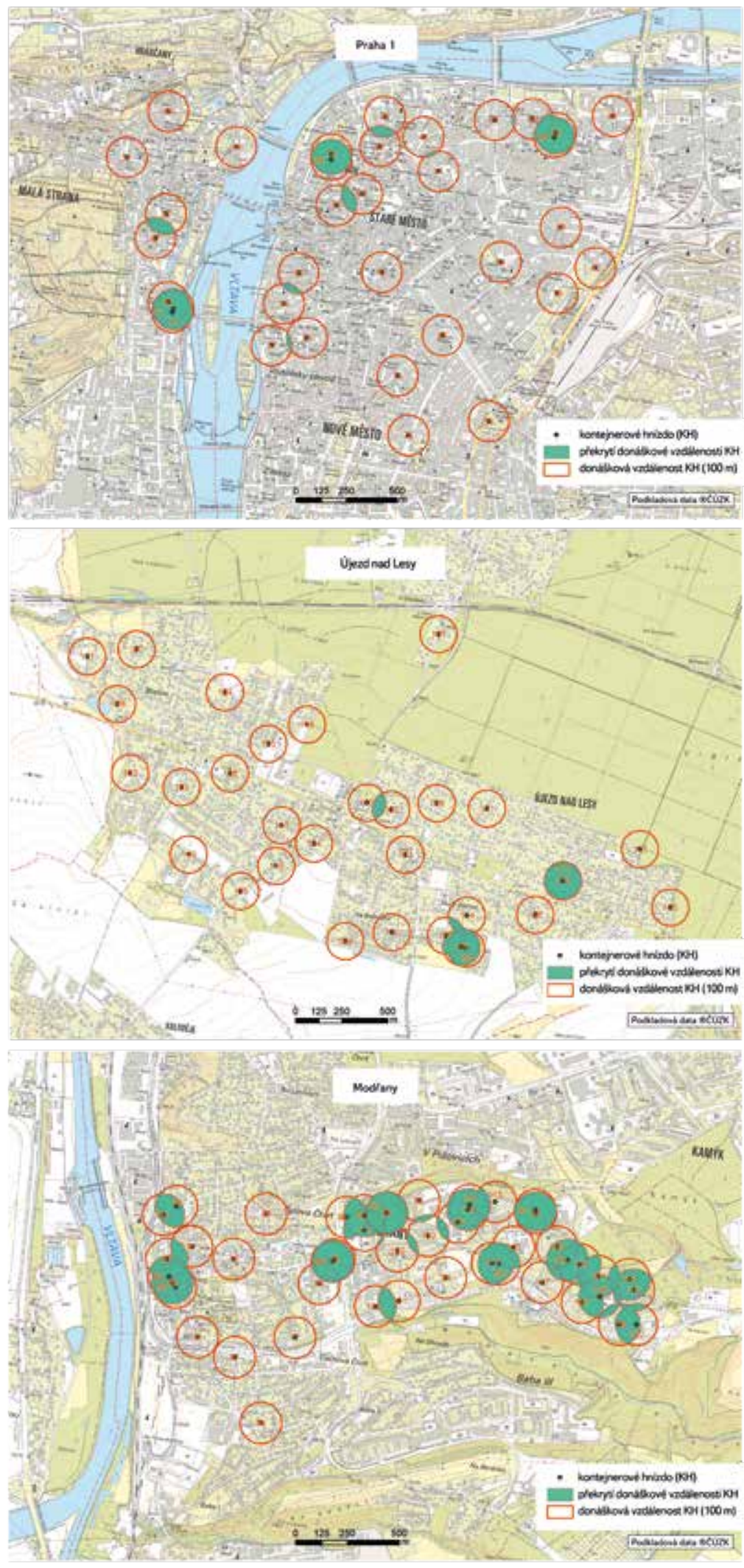

Obr. 1. Monitorovaná kontejnerová hnízda a překrytí donáškových vzdáleností (centráln

zástavba - Praha 1, sídlištní zástavba - Modřany, vilová zástavba - Újezd nad Lesy)
Fig. 1. Monitored container nests and overlapping delivery distances (central develop ment - Prague 1, housing development - Modřany, residential development - Újezd
Jako zástupce smíšené/centrální zástavby byly vybrány oblasti se staršími bytovými domy a s minimální zelení v jejich okolí, o kterou by se starali jejich obyvatelé.

Praha 1 (P1) je díky území Pražské památkové rezervace specifická. Kromě veřejně dostupných KH je přibližně 1000 sběrných míst umístěno prímo v bytových domech. Jedná se o kontejnery o objemu 0,12-0,24 m³ pro barevné sklo, papír a plast vyvážené $1 \times$ za 1-2 týdny. Při monitoringu nejsou tyto kontejnery evidovány z důvodu nedostupnosti. Při náhodné možnosti kontejner zkontrolovat Ize konstatovat, že neanonymní separace je efektivní a mnohem čistější než veřejná anonymní. To také potvrzují i vně umístěné kontejnery (např. pro papír) uzamykatelné pro konkrétní právnické osoby/obchody (obr. 2). Objemný odpad Ize odkládat na 12 místech, a to jeden den v každém měsíci [4]. Objemný odpad, jako např. elektrospotřebiče, lednice, sporáky, stavební sut', pneumatiky, Ize odložit ve sběrném dvoře. Nejbližší je sběrný dvưr hlavního města Prahy v ulici Perucká (Praha-Vinohrady) [4], kam Ize odložit i nebezpečné odpady. Biologicky rozložitelný odpad (BRO) je svážen velkoobjemovým kontejnerem jednou měsíčně z jednoho místa. Veřejně dostupný kontejner pro elektroodpad se nachází pouze v ulici Široká a Žitná. Pražské služby, a. s., zajištují i svoz gastroodpadu [5, 6]. Veřejně dostupné kontejnery pro textil jsou umístěny na Senovážném náměstí a jejich provoz zajištuje firma Potex [7].

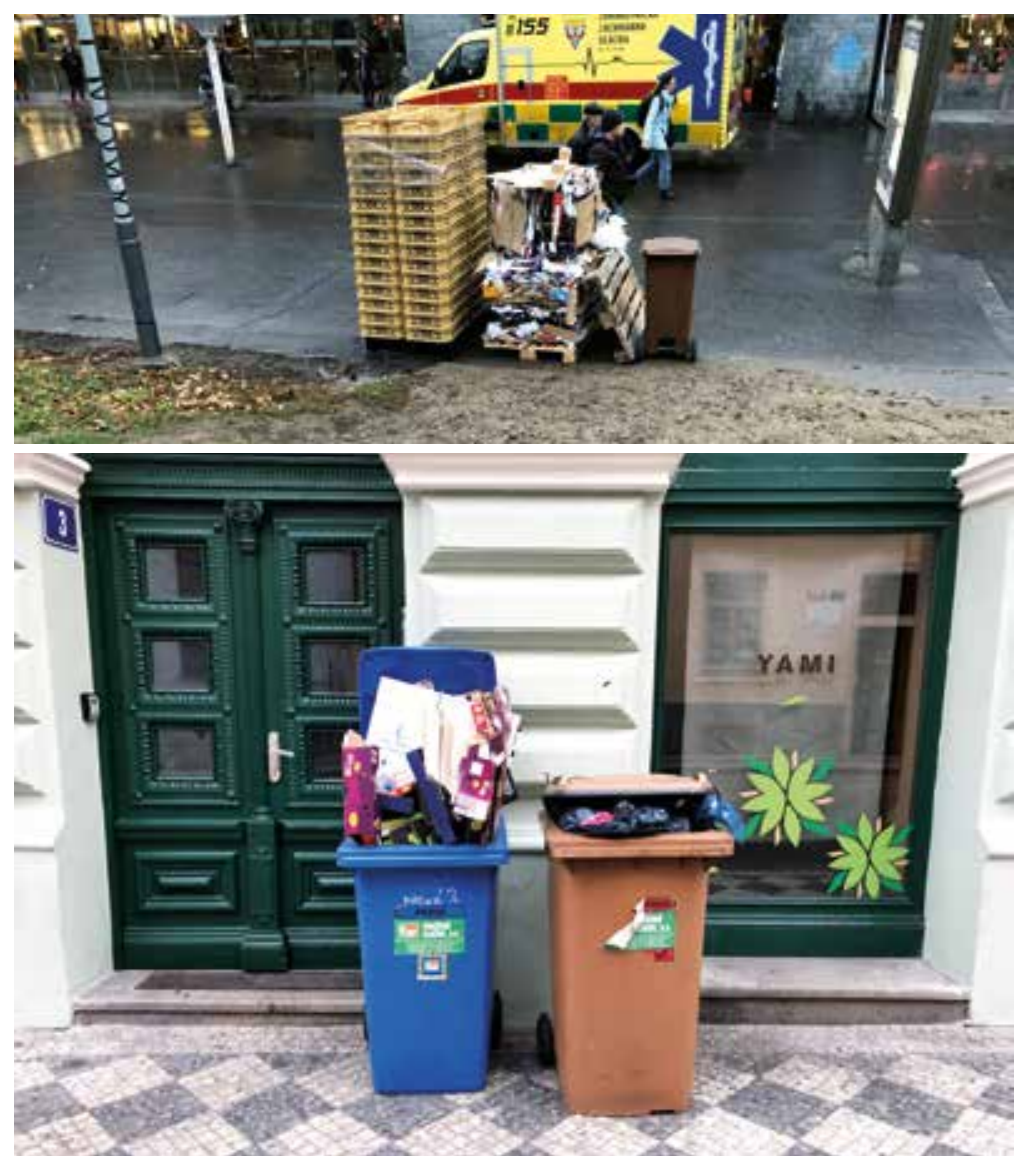

Obr. 2. Tříděný papír od právnické osoby

V Praze 6 (P6) je velkoobjemový kontejner přistavován na 9 místech v námi monitorované oblasti, a to jedenkrát za dva měsíce. Residenti, pokud mají u domu zahrady, využívají vlastní kompostéry nebo nádobu pro BRO, která je vyvážena 1x za dva týdny. Veřejně dostupný kontejner pro textil ve sledované oblasti není (dva jsou umístěny za frekventovanou silnicí v ulici Jugoslávských partyzánů). Kontejnery pro elektroodpad se nachází na Sibiřském náměstí. 
Tabulka 1. Počty sledovaných KH a jejich kapacity

Table 1. Numbers of monitored container nests and their capacity

Objem na 1 obyv. ve sledovaných lokalitách [I]

Sběrná nádoba/komodita

$\mathbf{P}$

\begin{tabular}{|c|c|c|c|c|c|c|c|c|}
\hline Počet sledovaných KH v oblasti & 30 & 20 & 19 & 32 & 15 & 27 & & \\
\hline papír a lepenka & 2,88 & 2,43 & 5,9 & 2,91 & 7,19 & 5,42 & 4,49 & $1-7 \times 1 t$ \\
\hline plasty VČ. PET & 2,88 & 2,20 & 2,3 & 3,09 & 3,76 & 5,56 & 3,61 & $1-7 \times 1 t$ \\
\hline sklo kombinované & 0,08 & 0,25 & 2,64 & 2,97 & 1,71 & 0 & 3,43 & $1 \times 1-2 \mathrm{t}(\mathrm{P} 1$ a $\mathrm{P} 6) ; 1 \times 6 \mathrm{t}$ \\
\hline sklo barevné & 1,38 & 1,82 & 1,9 & 1,45 & 4,12 & 8,11 & 2,82 & $1 \times 1-4$ t (P1 a P6); $1 \times 6 \mathrm{t}$ \\
\hline sklo čiré & 1,38 & 1,27 & 1,9 & 1,45 & 1,54 & 3,51 & 0,2 & $1 \times 1-4$ t (P1 a P6); $1 \times 6 \mathrm{t}$ \\
\hline nápojový karton & 0,77 & 10,6 & 1,9 & 1,25 & 1,79 & 2,15 & 1,62 & $1 \times 1 \mathrm{t}(0,24) ; 1 \times 2 \mathrm{t}(1,1)$ \\
\hline kovy & 0,89 & 0,25 & 0,21 & 0,87 & 0,38 & 0,56 & 0,54 & $1 \times 2-4 t(P 1) ; 1 \times 6 t$ \\
\hline $\mathrm{BRO}$ & - & - & - & 0,85 & - & - & & \\
\hline elektro & 0,16 & 0,16 & 2,07 & 5,30 & 3,67 & 1,36 & 0,25 & $1 \times 4 t$ \\
\hline textil & 0,27 & 0,27 & 0,96 & 0,41 & 2,56 & 0,95 & 0,36 & $1 \times 4 t$ \\
\hline
\end{tabular}
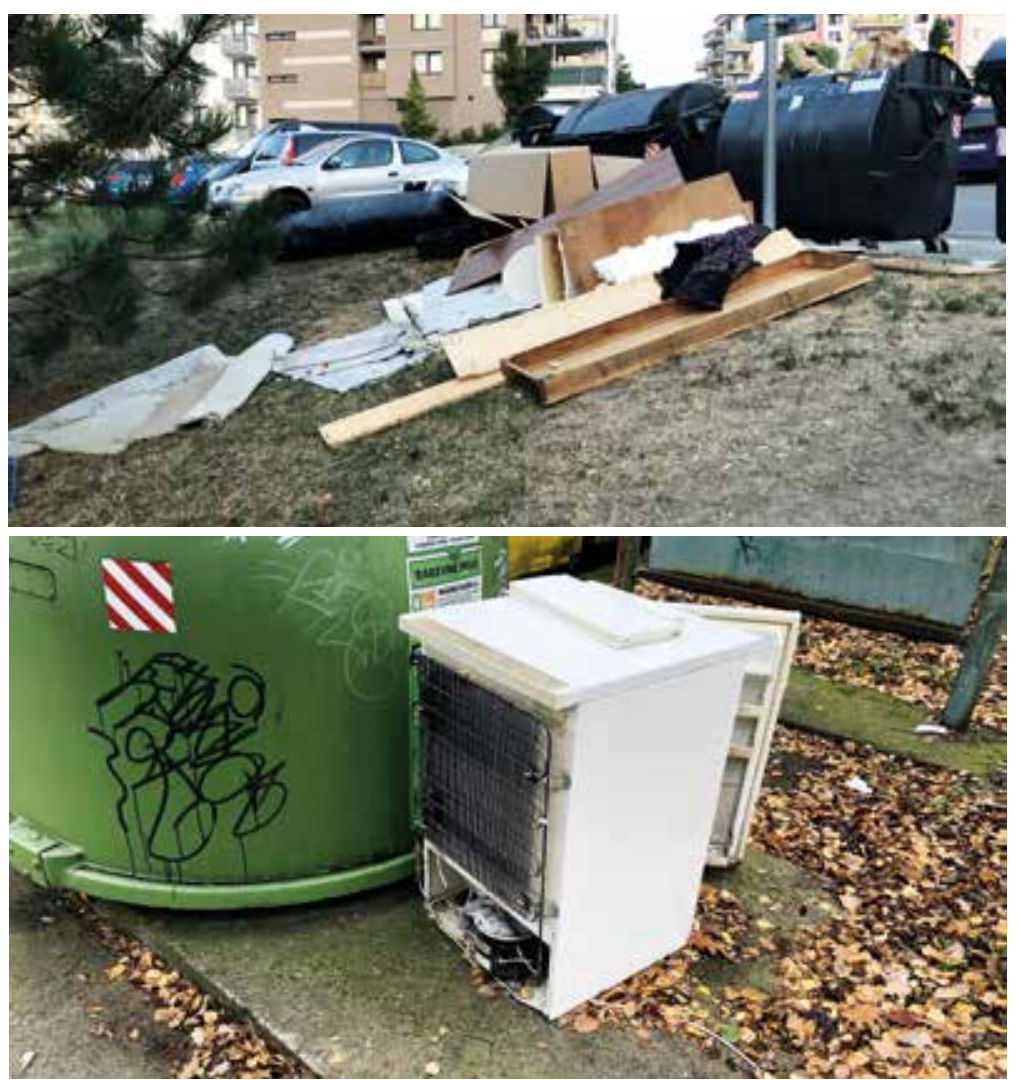

Obr. 3. Littering v blízkosti kontejnerových hnízd

Fig. 3. Littering near container nests
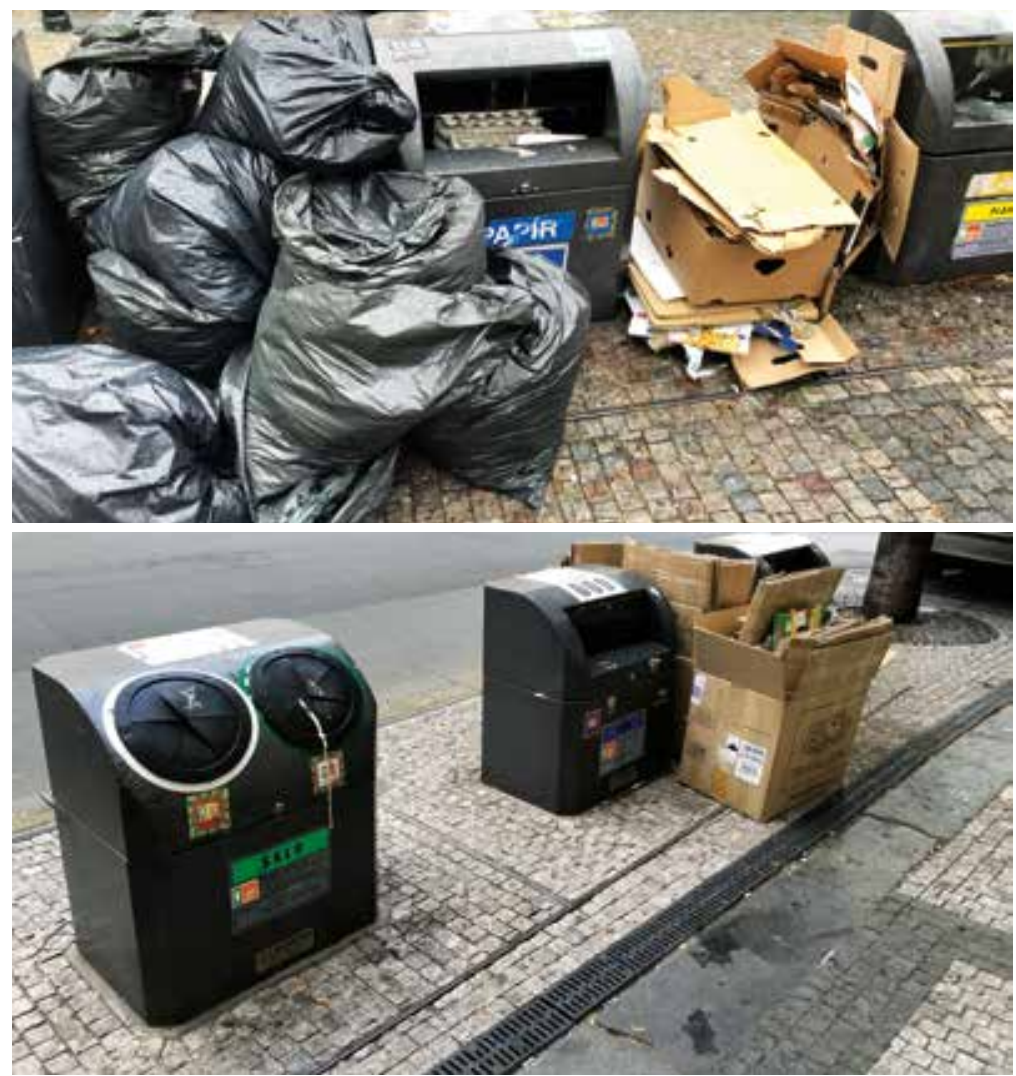

Obr. 4. Přeplněné kontejnery - výběr Praha 1 ul. Rytîrská a Masná

Fig. 4. Crowded containers - selection Praque 1 Rytířská and Masná street 

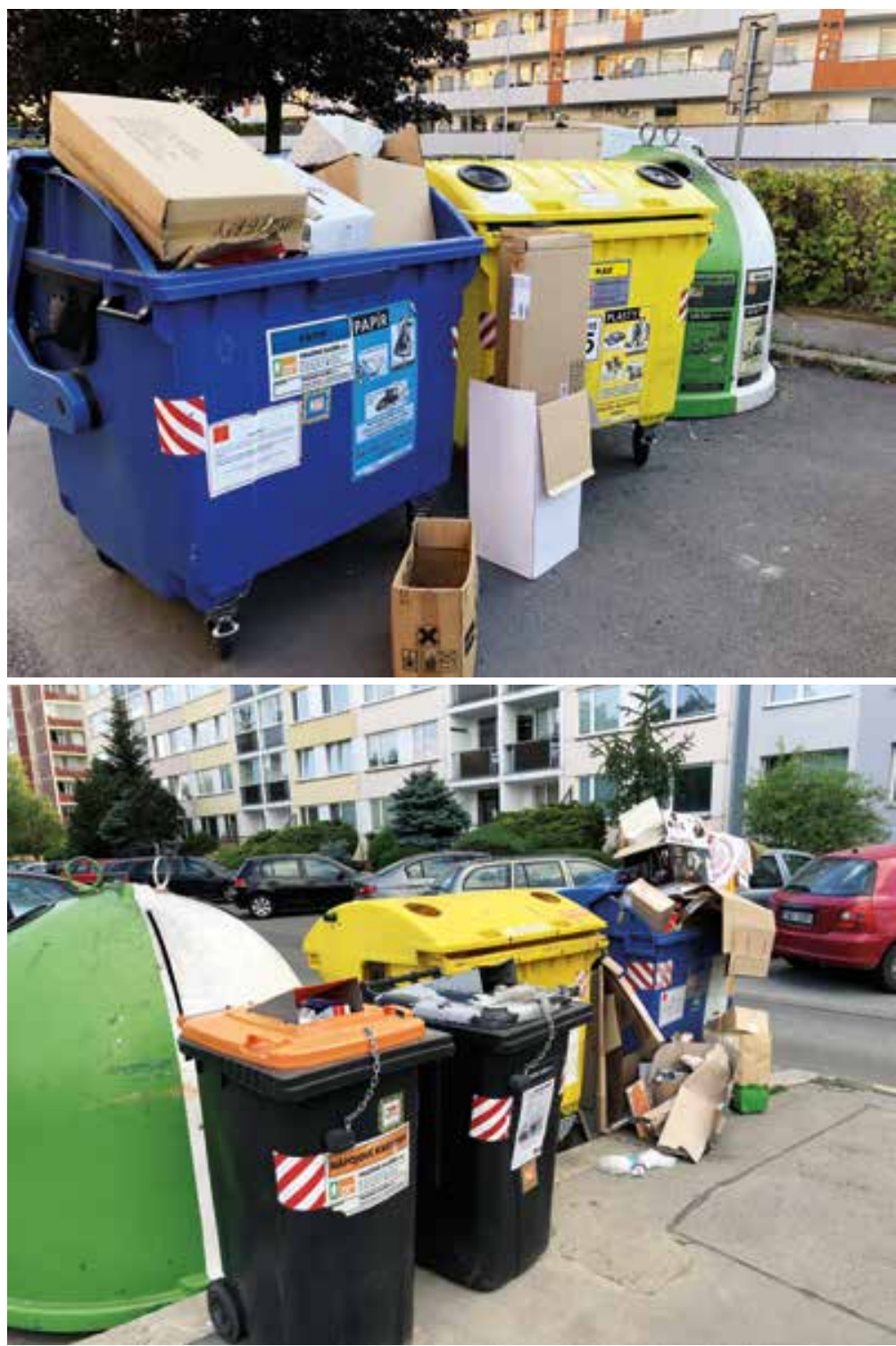

Obr. 5. Přeplněné kontejnery na papír - výběr Praha 15

Fig. 5. Crowded containers for paper waste - selection Prague 15

Sídlištní zástavbu představují sídliště s typickými panelovými domy z 80 a 90. let 20. století.

Praha 15 (P15) poskytuje informace o možnostech nakládání s odpady na velmi přehledných a aktualizovaných stránkách Městské části Praha 15 [8] Kontejner pro velkoobjemový odpad je ve sledované oblasti přistavován jednou měsíčně, a to na 48 místech podle půl roku předem zverejněného rozpisu. Sběrný dvưr je vzdálen cca 1,5 km. Textil Ize ukládat do tří kontejnerů Diakonie Broumov. BRO bylo možné odkládat do hnědých sběrných nádob, které byly vyváženy jedenkrát týdně. Stav těchto kontejnerů byl v projektu sledován, ale po ukončení pilotního projektu třídění BRO v prosinci 2018 se tento typ odpadu stal opět součástí směsného komunálního odpadu. Tento postup byl z pohledu obyvatelstva poměrně značně kritizován.

Praha 12 (P12) má velmi přehledně vypracované internetové stránky s informacemi pro občany [9]. Přistavování kontejneru na objemný a biologicky rozložitelný odpad je prováděno prakticky po celou dobu, a to $v$ intervalech minimálně $1 \times$ měsíčně u BRO na 22 stanovištích a pro objemný odpad na 32 stanovištích. $V$ mezidobí je možno odpady odevzdat na sběrném dvoře vzdáleného z nejbližšího místa sledované části 3,2 km.
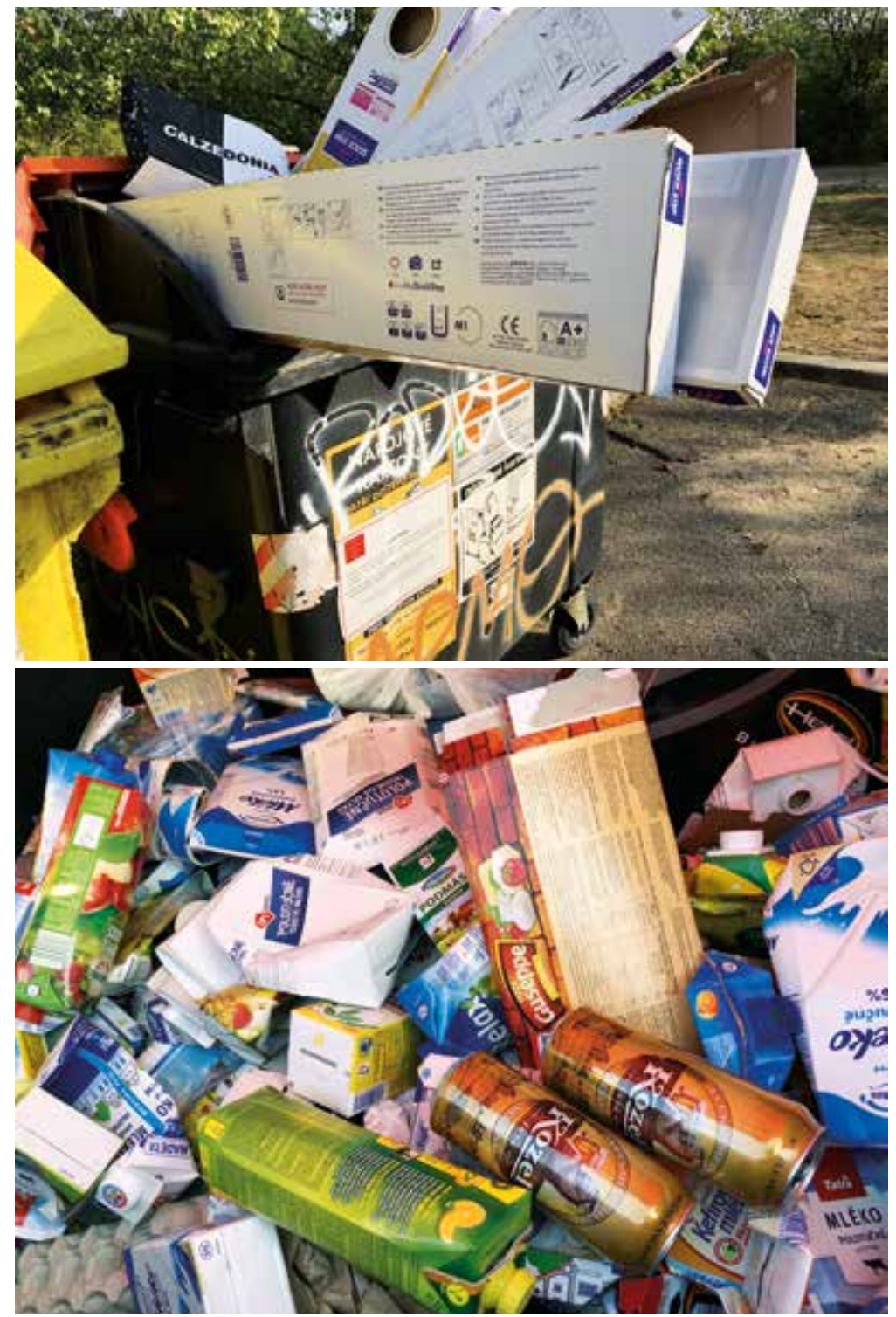

Obr. 6. Príměsi v kontejnerech pro nápojové obaly

Fig. 6. Admixtures in containers of beverage packaging

Vilová zástavba je tvořena rodinnými domy s rưzně velkými soukromými zahradami, na kterých je vyprodukováván ve větší míre i BRO. Většina domů není vytápěna tuhými palivy, tj. ve směsném komunálním odpadu se nenachází popel.

Praha 21 (P21) své občany informuje o způsobech nakládání s odpady na aktuálních přehledných webových stránkách [10]. Zájemcům byly poskytnuty hnědé kontejnery na separaci bioodpadu, které jsou vyváženy $1 \times$ za 14 dní. Velkoobjemový kontejner je přistavován $1 \times$ měsičně na minimálně dvou místech ve sledované oblasti. Nejbližší sběrný dvưr se nachází v sousední obci Běchovice vzdálený přibližně $3 \mathrm{~km}$.

\section{DISKUSE}

Hnízda kontejnerů pro tříděné složky komunálního odpadu je problematické zřizovat zejména z důvodu nedostatku ploch, a to jak na sídlištích, kde konkurují na parkovištích automobilům, tak v centru Prahy, kde je umístění KH kompromisem odpadové obslužnosti místních residentů a požadavků odboru památkové 

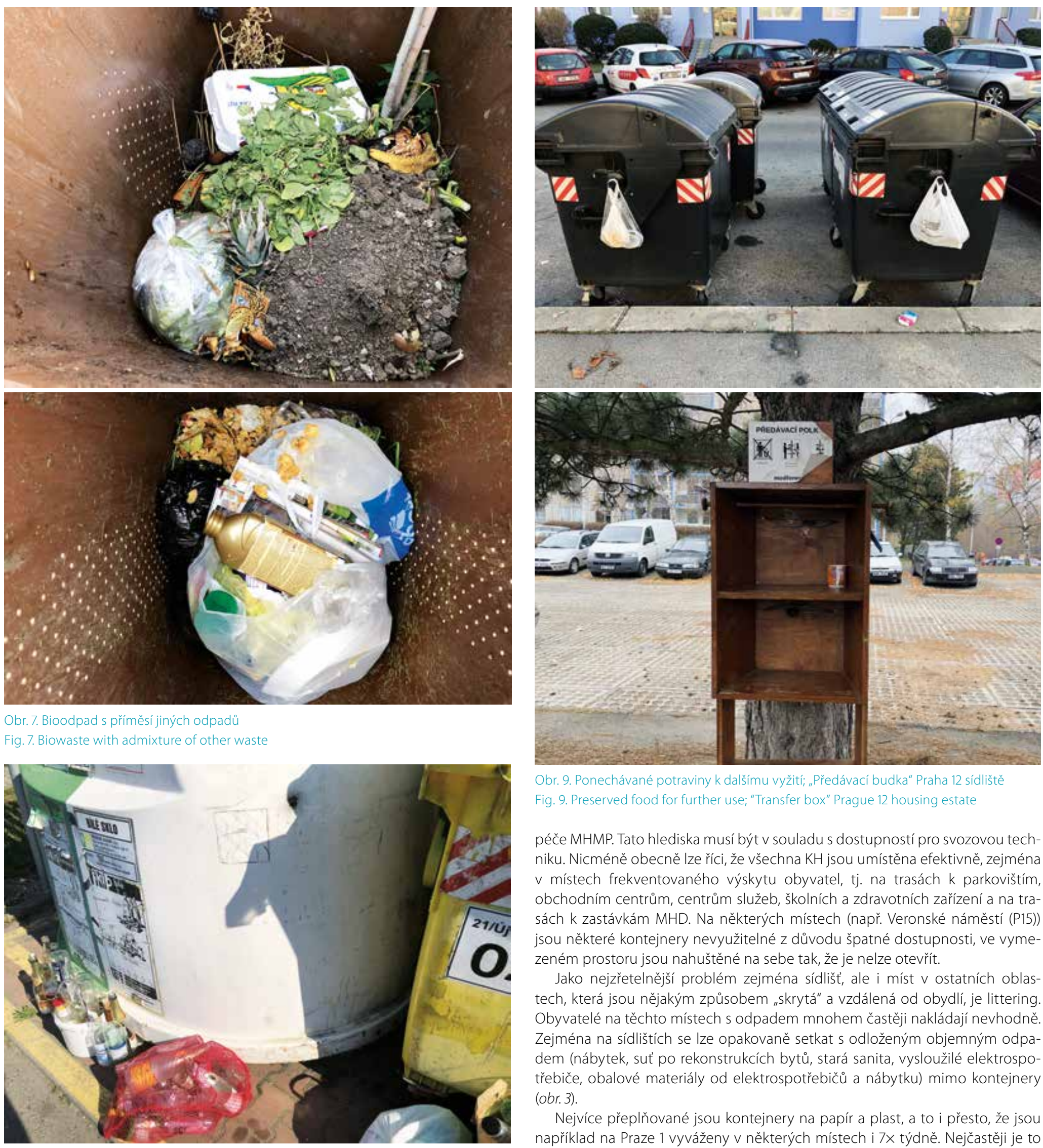

Obr. 9. Ponechávané potraviny k dalšímu vyžití; „Předávací budka“ Praha 12 sídliště Fig. 9. Preserved food for further use; "Transfer box" Prague 12 housing estate

péče MHMP. Tato hlediska musí být v souladu s dostupností pro svozovou techniku. Nicméně obecně Ize říci, že všechna KH jsou umístěna efektivně, zejména $\checkmark$ místech frekventovaného výskytu obyvatel, tj. na trasách k parkovištím, obchodním centrům, centrům služeb, školních a zdravotních zařizení a na trasách k zastávkám MHD. Na některých místech (např. Veronské náměstí (P15)) jsou některé kontejnery nevyužitelné z důvodu špatné dostupnosti, ve vymezeném prostoru jsou nahuštěné na sebe tak, že je nelze otevř́t.

Jako nejžretelnější problém zejména sídlišt, ale i míst v ostatních oblastech, která jsou nějakým způsobem "skrytá" a vzdálená od obydlí, je littering. Obyvatelé na těchto místech s odpadem mnohem častěji nakládají nevhodně. Zejména na sídlištích se Ize opakovaně setkat s odloženým objemným odpadem (nábytek, sut po rekonstrukcích bytů, stará sanita, vysloužilé elektrospotřebiče, obalové materiály od elektrospotřebičů a nábytku) mimo kontejnery (obr. 3).

Nejvíce přeplňované jsou kontejnery na papír a plast, a to i přesto, že jsou např́klad na Praze 1 vyváženy v některých místech i 7x týdně. Nejčastěji je to $\checkmark$ blízkosti restaurací (např. ul. Rytiřská, Vodičkova, Masná), provozoven služeb (např. kadeřnické a kosmetické salony; Milánská 413 (P15), Botevova 5 (P15), 
Levského 17 (P12), Modřanská 3 (P12)) anebo v místech, kde je v blízkosti hlavní komunikace, kde KH využívají i obyvatelé jiných pražských čtvrtí, resp. okolních obcí, při cestě do zaměstnání (např. ul. Generála Šišky (P12), Vazovova (P12), Račiněveská (P21)). Z tohoto důvodu nejsou do monitoringu zahrnuta KH v okrajových oblastech v místech parkovišt', kde parkoviště a KH využívají „přespolní" (ul. Gen. Šišky (P12)).

Z nepřiměřeně velkého rozdílu mezi naplněností jednotlivých $\mathrm{KH}$, která jsou vyvážena ve stejných intervalech, Ize usuzovat, že někteří drobní podnikatelé jsou zapojeni do systému obce vývozem nádob s neodpovídající potřebnou kapacitou, tj. mají nasmlouván vývoz nejmenší možné sběrné nádoby a pro vyprodukovaný tríděný odpad navíc využívají KH pro residenty (obr. 4).

Ve všech oblastech je v kontejnerech pro papír a plast častým problémem jejich nerozložení a nesešlapávání. Často byly v kontejnerech pro papír celé krabice, které zaplnily objem, a budily tak dojem plnosti kontejneru, a tím ovlivňovaly chování obyvatel, kteři pak zanechávali vytříděný papír vně kontejneru, nebo jej vhodili do nejbližšího prázdnějšího kontejneru (nejčastěji do kontejneru na nápojové kartony (NK)). Z tohoto hlediska se Ize domnívat, že jsou lepšl plechové kontejnery s úzkým vhozovým otvorem, než kontejnery s otevíracím víkem (obr. 5).

Nebylo výjimkou, že k KH byl donesen obal od elektroniky, tj. papírová krabice uvnitř s polystyrenem, který byl ponechán na zemi neroztříděný a nerozložený.

Dalším důvodem znečištění separované složky je její ponechání v donášené tašce/sáčku, který je z odlišného materiálu než separovaná složka. Z tohoto důvodu se často $v$ plastovém odpadu nacházejí papírové tašky a v papírovém odpadu, bioodpadu, kovovém odpadu nebo nápojových kartonech tašky/sáčky plastové.

Pokud je jeden z druhů kontejneru na separovaný odpad preplněn, velmi často se stává, že donesený vytř́iděný druh odpadu je položen vně kontejneru nebo je vhozen do nejbližšího prázdnějšího kontejneru, přestože je určen na jiný separovaný druh. Nejvíce jsou takto využívány kontejnery pro nápojové kartony, které v některých případech připomínají spíše kontejner pro SKO (obr. 6).

Sběr BRO byl monitorován na sídlišti P15, kde probíhal pilotní projekt sběru BRO do hnědých kontejnerů. Kontejnery nikdy nebyly plné, tj. byla optimálně nastavená četnost vyvážení. Jako problematické se jeví ponechávání bioodpadů $\vee$ plastových sáčcích nebo zeleniny a ovoce $\vee$ původním plastovém obalu, v kterém jsou prodávány. Další komplikací je znečištění kontejnerů po vyprázdnění a v teplých ročních obdobích výskyt hmyzu (obr. 7).

Umístění kontejnerů pro textil u školních a predškolních zařízení (P12), v blízkosti domu s pečovatelskou službou (P15), u obchodního centra nebo parkoviště (P12, P15) se zdá být velmi efektivní a v průběhu monitoring nebyl nikdy $\checkmark$ jejich okolí nalezen nepořádek.

$\checkmark$ oblastech, kde nejsou kontejnery pro separaci kovu, je znatelná jejich potřeba, a to zejména nyní, kdy se zvýšila prodejnost nápojů v hliníkových obalech a hliníkových a kovových nádob s krmivy pro domácí mazlíčky. V případě jejich separace a nepř́tomnosti kontejneru pro kov jsou tyto odpady nejčastěji vhazovány do kontejnerů pro nápojové kartony. Podle našeho pozorování by bylo vhodné zvýšit počet vyvážení v letních měsících. Zvýšená obliba a prodej nápojů v tomto druhu obalu byl znatelný podle obsahu kontejnerů i pouličních odpadkových košů [10].

V blízkosti restaurací (např. Valdštejnské nám.) nebo sídlištích se často vyskytují celé kuchyňské nádoby nebo střepy z porcelánu. V lepším prípadě jsou nechávány vně kontejneru, často se ale nacházejí v barevném či směsném skle.

Ze všech tříděných druhů odpadů bylo nejméně problematické bílé sklo, následně pak sklo barevné či směsné. $\vee$ ojedinělých prípadech byly $\vee$ kontejneru nalezeny také zářivky. Nastavení vývozu se jeví jako dostatečné. Pouze $\checkmark$ letních měsících, kdy je obecně větší spotřeba nápojů ve skleněných obalech, bylo jejich vyvážení nedostatečné (zejména v P 21, obr. 8).
Na sídlištích jsou často u KH (ale také u kontejnerů na SKO) vně ponechávány potraviny, oděvy nebo ještě použitelné objemné odpady. Chybí reuse centra nebo místa možného predávání (viz existující, avšak málo využívaná Předávací budka P 12, obr. 9).

\section{ZÁVĚR}

Na základě dosavadního monitoringu odpadové obslužnosti ve vybraných lokalitách na území hlavního města Prahy Ize konstatovat, že technologie odděleného sběru využitelných složek komunálního odpadu je poměrně dobře nastavená. Jako hlavní důvod znečištování separovaných druhů odpadů se jeví určitá nedisciplinovanost nebo částečná neznalost obyvatel. Magistrát hlavního města Prahy spolu s Pražskými službami, a. s., se snaží navyšovat kapacity kontejnerů pro separované složky komunálního odpadu, a to bud' výměnou za větší druh kontejneru, nebo, zejména na Praze 1, zrízením podzemních kontejnerů. V průběhu sledování docházelo i k zhuštování sítě kontejnerů pro kovový odpad a podle aktuálních informací se také uvažuje o zmenšení potřebného prostoru hnízd kontejnerů sloučením kontejnerů pro plastový odpad a nápojové obaly v jeden. Občané jsou kampaněmi motivováni k zmenšování objemu tříděných odpadů a udržování čistoty v okolí kontejnerů. Informace o nakládání s odpadem jsou dostupné na internetových stránkách Magistrátu hlavního města Prahy, Pražských služeb, a. s., a jednotlivých městských částí, které tyto informace zároveň širíi i písemnou formou; přesto je zřejmé, že v separaci vybraných složek odpadů jsou značné rezervy, které rovněž sledujeme při rozboru SKO ze sledovaných oblastí. Konečné návrhy na nastavení reálně dosažitelných cílů a indikátorů jejich plnění v oblasti nakládání s komunálními odpady budou součástí závěrečné zprávy řešeného projektu v polovině roku 2020.

\section{Poděkování}

Př́spěvek vznikl za podpory projektu CZ.07.1.02/0.0/0.0/16_040/0000379 Odpady a predcházení jejich vzniku - praktické postupy a činnosti prì realizaci závazků krajského Plánu odpadového hospodářství hlavního města Prahy.

\section{Literatura}

[1] Krajský Plán odpadového hospodárštví hlavního města Prahy na období 2016-2025 (Portál životního prostředíhlavního mésta Prahy) [online]. [vid. 2. zář́ 2019]. Dostupné z: http://portalzp.praha.eu/jnp/cz/ odpady/koncepcni_dokumenty/POH_hlmPrahy_krajsky_2016.html

[2] KUBÁŇ, D. Sociodemografická studie se zaměrením na oblasti svozu komunálního odpadu, 2018.

[3] Odpady a předcházeníjejich vzniku (Vúv TGM, v. v. i.) [online]. [vid. 30. srpen 2019]. Dostupné z: https:// heis.vuv.cz/data/webmap/datovesady/projekty/polrustu2odpady/default.asp?

[4] Odpady. Praha 1 [online]. [vid. 22. srpen 2019]. Dostupné z: https://www.praha1.cz/cistota-a-zivotni-prostredi/odpady/

[5] Mapa sběrných dvorů a dalších vybraných zařízení k nakládání s odpady v hl. m. Praze. Praha. eu-portál hlavního města Prahy [online]. [vid. 22. srpen 2019]. Dostupné z: http://www.praha.eu/jnp/ cz/o_meste/zivot_v_praze/sluzby/odpady/sberne_dvory/mapa_sbernych_dvoru/index.html

[6] GASTRO ODPAD - biologicky rozložitelný odpad z kuchynía stravoven - Pražské služby, a. s. Pražské služby [online]. [vid. 22. srpen 2019]. Dostupné z: https://www.psas.cz/index.cfm/o-spolecnosti/ nove-projekty/gastro-odpad-kuchyne-stravovny/

[7] VLADIMIR@GRAPHICLOVERS.CZ, D. by V. S. RecyklujemeTextil.cz. RecyklujemeTextil.cz [online]. [vid. 22. srpen 2019]. Dostupné z: https://www.recyklujemetextil.cz/kde-najdete-kontejnery

[8] Městská část Praha 15 - Kontejnery. Městská část Praha 15 [online]. [vid. 23. srpen 2019]. Dostupné z: https://www.praha15.cz/urad/odbory-uradu/odbor-zivotniho-prostredi/kontejnery/

[9] Odpady: Praha 12. Praha 12 [online]. [vid. 23. srpen 2019]. Dostupné z: https://www.praha12.cz/ odpady/ds-1138/p1=64331

[10] Odpadové hospodářství P 21. Praha 21 [online]. [vid. 23. srpen 2019]. Dostupné z: http://www. praha21.cz/temata/odpadove-hospodarstvi\#.XV-fC-gzaUm 


\title{
Autoři
}

Ing. Dagmar Vološinová

凶dagmar.volosinova@vuv.cz

Ing. Robert Kořínek, Ph.D.

凶robert.korinek@vuv.cz

Ing. Marcela Makovcová

凶marcela.makovcova@vuv.cz

Výzkumný ústav vodohospodářský T. G. Masaryka, v. v. i.

Příspěvek prošel lektorským řízením.

\section{MONITORING OF WASTE SERVICES FOR SORTED COMPONENTS OF MUNICIPAL WASTE IN THE CAPITAL CITY OF PRAGUE}

\section{VOLOSINOVA, D.; KORINEK, R.; MAKOVCOVA, M.}

TGM Water Research Institute, p.r.i.

Keywords: waste - waste management sorting - municipal waste - monitoring

\begin{abstract}
Management of each municipality, region or state needs for its decision-making and planning basic input data, which prove actual facts. The easiest way to obtain data on production and waste management is to monitor at pre-set regular intervals. This article describes the progress and partial results of the monitoring of waste services in the Capital City of Prague, which is carried out within the framework of the project "Wastes and their prevention - practical procedures and activities in implementation of obligations of the Regional Waste Management Plan of the City of Prague".
\end{abstract}

